\title{
Profil Kemampuan Koneksi Matematis Mahasiswa dalam Menyelesaikan Masalah pada Mata Kuliah Kalkulus 1 ditinjau berdasarkan Gaya Kognitif
}

\author{
Rezi Ariawan ${ }^{1}$, Hayatun Nufus ${ }^{2}$ \\ ${ }^{1}$ Pendidikan Matematika Universitas Islam Riau \\ 2 Pendidikan Matematika, Universitas Islam Negeri Sultan Syarif Kasim Riau \\ e-mail: reziariawan@edu.uir.ac.id, hayatun.nufus@uin-suska.ac.id
}

\begin{abstract}
ABSTRAK. Penelitian ini bertujuan untuk mendeskripsikan profil kemampuan koneksi matematis mahasiswa dalam menyelesaikan masalah pada mata kuliah kalkulus 1 ditinjau berdasarkan gaya kognitif. Penelitian ini merupakan penelitian kualitatif dengan subjek penelitian adalah mahasiswa pendidikan matematika FKIP UIR yang sudah lulus mata kuliah kalkulus 1. Instrumen pengumpulan data terdiri dari lembar tes tertulis, lembar tes GEFT dan lembar pedoman wawancara. Analisis data dilakukan dengan menganalisis data tertulis wawancara yang kemudian selanjutnya dilakukan triangulasi metode untuk mendapatkan data subjek penelitian yang valid. Berdasarkan hasil penelitian diperoleh bahwa profil kemampuan koneksi matematis mahasiswa yang mempunyai gaya kongitif Field Independent, Field Medium, dan Field Dependent sudah mampu mengkoneksikan konsep matematika dengan konsep disiplin ilmu lainnya. Mahasiswa yang bergaya kognitif Field Independent, Field Medium, dan Field Dependent belum memiliki kemampuan untuk mengkoneksikan konsep matematika dengan konsep matematika serta belum mampu mengkoneksikan konsep matematika dengan permasalahan sehari-hari.
\end{abstract}

Keywords : kemampuan koneksi matematis, kalkulus 1, gaya kognitif

\section{PENDAHULUAN}

Pembelajaran matematika di perguruan tinggi mempunyai peranan yang sangat penting dalam mengembangkan kemampuan berpikir, memecahkan masalah dan kemandirian belajar. Koko (1990: 2) menjelaskan bahwa tujuan pembelajaran matematika diperguruan tinggi adalah untuk memperoleh pengetahuan dasar dan pola pikir matematika dalam bentuk: (1) tertatanya pola pikir ilmiah yang kritis, logis, dan sistematis; (2) terlatihnya daya nalar dan kreativitas setelah mempelajari berbagai strategi dan taktik dalam pemecahan masalah kalkulus; (3) terlatih dalam merancang model matematika sederhana; (4) terampil dalam teknik matematika yang baku dengan didukung oleh konsep, penalaran, rumus, dan metode yang benar.

Kemampuan koneksi matematis sangat diperlukan sejak dini oleh setiap peserta didik termasuk di dalamnya mahasiswa. Menurut NCTM (2000: 274) Koneksi matematis merupakan salah satu hal penting dalam berpikir matematis dan dapat membangun pemahaman matematis. Tanpa koneksi, mahasiswa harus mempelajari dan mengingat terlalu banyak konsep dan keterampilan. Dengan koneksi, mereka dapat membangun pemahaman baru dari pengetahuan sebelumnya. Hal ini karena melalui koneksi matematis maka pandangan dan pengetahuan mereka akan semakin luas terhadap matematika sebab semua yang terjadi di kehidupan sehari-hari maupun materi yang dipelajari saling berhubungan. Melalui koneksi pula, konsep pemikiran dan wawasan mahasiswa akan semakin terbuka dan luas terhadap matematika karena mereka akan memandang matematika sebagai suatu bagian yang terintegrasi bukan sebagai sekumpulan topik yang terpisah-pisah, serta mengakui adanya keterkaitan atau hubungan dan aplikasi di dalam 
kehidupan atau lingkungan sekitar mereka. Karena topik-topik dalam matematika banyak memiliki relevansi dengan disiplin ilmu lain, baik di kelas maupun di luar kelas.

Hal ini sejalan dengan apa yang dikemukakan Utari Sumarmo. Menurut Sumarmo (2013: 39), dalam belajar matematika mahasiswa dituntut memahami koneksi antara ide-ide matematis dan antar matematika dan bidang studi lainnya karena topik-topik dalam matematika banyak memiliki relevansi dan manfaat dengan bidang lain, baik di sekolah maupun di luar sekolah. Jika mereka sudah mampu melakukan koneksi antara beberapa ide matematis, maka mereka akan memahami setiap materi matematika dengan lebih dalam dan baik. Selain itu, melalui koneksi konsep pemikiran dan wawasan mahasiswa akan semakin terbuka dan luas terhadap matematika karena mereka akan memandang matematika sebagai suatu bagian yang terintegrasi bukan sebagai sekumpulan topik yang terpisah-pisah, serta mengakui adanya keterkaitan atau hubungan dan aplikasi di dalam kehidupan atau lingkungan sekitar mereka.

Selanjutnya, karena salah satu materi yang sering memiliki koneksi (baik koneksi antar topik matematika maupun dengan bidang lain serta kehidupan sehari-hari) adalah materi kalkulus diferensial (kalkulus I), maka perlu diteliti kemampuan koneksi matematis pada materi kalkulus diferensial (kalkulus I) dan untuk dapat mewujudkan penguasaan konsep mahasiswa yang baik terhadap kalkulus 1.

Dalam melakukan suatu koneksi matematis, seseorang tentu sangat dipengaruhi oleh bagaimana ia berpikir. Setiap individu memiliki cara-cara tersendiri yang dilakukan dalam menyusun pikirannya, apa yang dilakukannya, dilihat, dan apa yang diingat. Individu juga akan memiliki cara-cara yang berbeda atas pendekatan yang dilakukannya terhadap situasi belajar, dalam cara mereka menerima, mengorganisasi, serta menghubungkan pengalaman-pengalaman mereka dalam cara mereka merespon terhadap metode pengajaran tertentu. Perbedaan yang melekat pada setiap individu dalam cara mengolah informasi dan menyusunnya dari pengalamanpengalamannya lebih dikenal dengan istilah gaya kognitif.

Menurut Anita (1993: 129), gaya kognitif adalah suatu cara yang berbeda untuk melihat, mengenal, dan mengorganisasi informasi. Setiap individu memiliki cara tertentu yang disukai dalam memproses dan mengoranisasi informasi sebagai respon terhadap stimulasi lingkungannya. Gaya kognitif seseorang dapat menunjukkan variasi individu dalam hal perhatian, penerimaan informasi, mengingat, dan berpikir yang muncul atau berbeda di antara kognisi dan kepribadian. Selanjutnya Sternberg dan Elena (1997: 701) menyatakan bahwa gaya kognitif adalah jembatan antara kecerdasan dan kepribadian. Gaya kognitif mengacu pada karakteristik seseorang dalam menganggapi, memproses, menyimpan, berpikir, dan menggunakan suatu tugas atau berbagai jenis situasi lingkungan.

Berdasarkan pendapat di atas, maka dapat disimpulkan bahwa gaya kognitif adalah karakteristik yang dimiliki oleh seseorang yang telah melekat dalam diri individu tersebut atau dapat dikatakan sebagai habitual approach yang terlihat dalam hal bagaimana individu tersebut menanggapi, memproses, berpikir, dan menggunakan informasi untuk menghadapi suatu permasalahan. Akibatnya mahasiswa yang merupakan seorang individu juga pasti akan memiliki karakteristik yang berbeda dalam hal menyelesaikan permasalahan yang dihadapinya dalam pembelajaran.

Menurut Witkin (1977: 13), dimensi gaya kognitif terdiri dari Field Independeent (FI) dan Field Dependent (FD). Field Dependent memiliki karakteristik, diantarany: (1) Cenderung memiliki pemikiran global; (2) Kecenderungan untuk menerima struktur yang sudah ada, disebabkan kurang memiliki restrukturisasi; (3) Memiliki orientasi sosial sehingga tampak baik, ramah, bijaksana, baik budi dan penuh kasih sayang terhadap yang lain; (4) Cenderung memilih profesi yang menekankan pada keterampilan sosial; (5) Cenderung mengikuti tujuan yang sudah ada; (6) Cenderung bekerja dengan mementingkan motivasi eksternal dan lebih tertarik pada penguatan eksternal seperti pujian, hadiah, atau motivasi eksternal dari orang lain. Individu Field Independent pada umumnya lebih kepada independent, kompetitif, dan percaya diri, sedangkan individu Field 
Dependent lebih cenderung bersosialisasi, menyatukan diri dengan orang-orang disekitar mereka, dan biasanya lebih berempati dan memahami perasaan orang lain.

O’Brien et al (dalam Suryanti: 2014: 1394) menyatakan perbedaan antara individu Field Dependent dan Field Independent, yaitu: Individu Field Independent memiliki ciri-ciri sebagai berikut: (1) Memiliki analisis yang lebih tinggi dalam penerimaan dan pemprosesan informasi, sehingga sering disebut sebagai "analytical thinkesr"; (2) Menunjukkan kecenderungan untuk mengorganisasikan informasi menjadi unit-unit yang dapat dikelola dan memiliki kapasitas yang lebih besar untuk penyimpanan informasi. Orang atau indvidu yang tergolong ke dalam Field Independent terbiasa menggunakan teknik pemecahan masalah, organisasi, analisis dan penataan ketika telibat dalam situasi belajar dan bekerja. Individu Field Dependent memiliki ciri-ciri sebagai berikut: (1)Peserta didik dengan Field Dependent lebih global dan holistik dalam pengolahan persepsi dan informasi sehingga sering disebut sebagai "global thinkers"; (2) Cenderung menerima informasi seperti yang disajikan atau dijumpai dan mengandalkan sebagian besar pada cara menghafal.

Selanjutnya Idris dalam Ulya (2015: 3) mengidentifikasi ada 3 tipe gaya kognitif yaitu Field Dependent (FD), Field Intermediate (FDI), Field Independent (FI). Masih menurut Idris, individu FD cenderung bekerja dengan motivasi eksternal, yaitu mencari bimbingan dan petunjuk dari orang lain. Individu FDI cenderung memiliki kemampuan seperti siswa FD atau FI karena terletak diantara keduanya. Individu FI memandang persoalan secara analitis, mampu menganalisis dna mengisolasi rincian yang relevan, mendeteksi pola dan mengevaluasi secara kritis suatu persoalan. Berdasarkan pendapat di atas, maka gaya kongnitif dalam penelitian ini peneliti bagi menjadi tiga kategori yaitu Field Independent (FI), Field Medium (FM), dan Field Dependent (FD).

Berdasarkan latar belakang dan pentingnya masalah yang telah dikemukan di atas, maka masalah yang dikaji dalam penelitian ini adalah: (1) Bagaimanakah profil kemampuan koneksi matematis mahasiswa dalam menyelesaikan masalah pada mata kuliah kalkulus 1 yang memiliki gaya kognitif Field Independent?; (2) Bagaimanakah profil kemampuan koneksi matematis mahasiswa dalam menyelesaikan masalah matematis pada mata kuliah kalkulus 1 yang memiliki gaya kognitif Field Medium?; (3) Bagaimanakah profil kemampuan koneksi matematis mahasiswa dalam menyelesaikan masalah matematis pada mata kuliah kalkulus 1 yang memiliki gaya kognitif Field Dependent?.

\section{METODE PENELITIAN}

Penelitian ini merupakan penelitian kualitatif. Menurut Moleong (2014: 8-13) penelititian kualitatif mempunyai ciri-ciri: (1) mempunyai latar alami; (2) peneliti sebagai instrumen utama; (3) menggunakan metode kualitatif; (4) analisis data secara induktif; (5) teori dari dasar (grounded theory); (6) bersifat deskriptif; (7) lebih mementingkan proses daripada hasil; (8) adanya batas yang ditentukan oleh fokus penelitian; (9) adanya kriteria untuk keabsahan data; (10) desain penelitian bersifat sementara; dan (11) hasil penelitian dirundingkan dan disepakati bersama.

Senanda dengan pendapat di atas, Bogdan dan Biklen dalam Emzir (2012: 2) menyatakan bahwa terdapat lima ciri utama penelitian kualitatif, yaitu; (1) naturalistik: memiliki latar aktual sebagai sumber langsung data dan peneliti merupakan instrumen kunci; (2) data deskriptif: data yang dikumpulkan lebih mengambil bentuk kata-kata atau gambar-gambar daripada angka-angka; (3) berurusan dengan proses: penelitian kualitatif lebih menekankan kepada proses daripada hasil atau produk; (4) induktif: penelitian kualitatif cenderung menganalisis data secara induktif, dan tidak melakukan pencarian di luar data atau bukti untuk menolak sebuah hipotesis.

Berdasarkan beberapa pendapat di atas, maka pendekatan penelitian ini adalah penelitian kualitatif. Disebut penelitian kualitatif karena prosedur penelitiannya menghasilkan data deskriptif berupa kata-kata tertulis atau lisan dari orang-orang atau tentang perilaku yang diamati.

Subjek dalam penelitian ini adalah mahasiswa semester 2 Program Sudi Pendidikan Matematika FKIP UIR semester genap yang sedang menempuh mata kuliah kalkulus 2 dengan peneliti sebagai dosennya yang berjumlah 33 orang. Pemilihan subjek penelitian ini didasari oleh beberapa pertimbangan, yaitu: (a) mahasiswa semester 2 yang sedang belajar kalkulus 2 dengan 
peneliti sudah mendapatkan mata kuliah kalkulus 1; (b) mudah diwawancarai sehingga akan diperoleh data akurat yang dibutuhkan dalam penelitian ini.

Untuk mendapatkan data tentang kemampuan subjek dalam menyatakan pendapat, ide, dan gagasan secara tulisan dengan jelas, maka peneliti membutuhkan instrumen bantu berupa tes kemampuan koneksi matematis, yang pada akhirnya dinyatakan oleh peneliti sebagai instrumen bantu pertama. Sedangkan untuk mendapatkan data berupa kemampuan subjek dalam menyatakan ide, gagasan dan pendapat secara lisan dengan jelas, maka peneliti membutuhkan lembar wawancara, yang pada akhirnya peneliti namakan sebagai instrumen bantu kedua. Selanjutnya untuk dapat menyatakan gaya kognitif individu, maka peneliti membutuhkan lembar tes GEFT yang pada akhirnya peneliti namakan sebagai instrumen bantu ketiga.

Analisis data dilakukan berdasarkan data tes tertulis dan data hasil wawancara. Data yang telah terkumpul dianalisis dengan langkah-langkah: (1) Reduksi data yakni melakukan proses pemilihan, penyederhanaan, dan transformasi data di lapangan. Dalam proses ini peneliti melakukan pemilihan subjek berdasarkan gaya kognitif, kejelasan dalam tulisan yang selanjutnya akan dilakukan wawancara; (2) Pemaparan data yakni pengklasifikasian dan mengidentifikasi data sehingga terorganisir dan terkategori dengan baik. Dalam hal ini peneliti melakukan telaah terhadap hasil tes tertulis, hasil wawancara berdasarkan gaya kognitif yang sudah ditentukan; (3) Menarik kesimpulan berdasarkan hasil paparan data. Dalam hal ini peneliti melakukan triangulasi metode untuk mendapatkan data subjek yang valid.

\section{HASIL PENELITIAN DAN PEMBAHASAN}

Penentuan gaya kognitif mahasiswa berdasarkan pengisian instrumen GEFT. Seluruh mahasiswa yang merupakan subjek penelitian melakukan pengisian instrumen GEFT. Berikut akan data yang diperoleh dari pengisian instrumen GEFT tersebut.

Tabel 1. Rekapitulasi Jumlah Subjek Penelitian Berdasarkan Kategori Gaya Kognitif

\begin{tabular}{ccc}
\hline Kategori Gaya Kognitif & Jumlah Mahasiswa & Persentase (\%) \\
\hline Field Independent & 2 Orang & 6,06 \\
\hline Field Medium & 8 Orang & 24,24 \\
\hline Field Dependent & 23 Orang & 69,69 \\
\hline Jumlah & 33 Orang & 100 \\
\hline
\end{tabular}

Berdasarkan Tabel 1 di atas terlihat bahwa sebagian besar, subjek penelitian termasuk ke dalam kategori gaya kognitif Field Dependenti dan hanya sedikit sekali subjek penelitian yang termasuk ke dalam kategori gaya kognitif Field Independent. Ini berarti, berdasarkan teori yang ada secara keseluruhan subjek penelitian yang peneliti gunakan adalah individu yang belum memiliki kemampuan menganalisis yang baik serta individu yang lebih suka belajar secara berkelompok dan lebih mudah bersosialisasi.

Dari informasi pada Tabel 1 di atas, maka peneliti memilih 3 subjek penelitian yang akan peneliti lakukan penelitian lanjutan, dimana ketiga subjek tersebut akan menyelesaikan soal tes kemampuan koneksi matematis dan akan peneliti wawancara. Kriteria penetapan subjek tersebut yaitu, peneliti memilih subjek dengan gaya kognitif Field Independent yang memiliki skor tes Instrumen GEFT yang paling tertinggi dengan pertimbangan agar tidak mudah berpindah ke dalam kategori gaya kognitif Field Medium, kemudian untuk subjek dengan gaya kognitif Field Medium peneliti memilih subjek yang memiliki skor tes yang ditengah dengan pertimbangan agar tidak berubah ke dalam kategori gaya kognitif Field Independent maupun Field Dependent, kemudian untuk subjek dengan gaya kognitif Field Dependent peneliti memilih subjek yang memiliki skor yang paling rendah dengan pertimbangan agar tidak berpindah ke dalam kategori gaya kognitif Field Medium. Berikut data subjek yang memenuhi kriteria pemilihan subjek berdasarkan gaya kognitif. 
Tabel 2. Mahasiswa yang Memenuhi Kriteria Subjek Penelitian Berdasarkan Gaya Kognitif

\begin{tabular}{ccccccc}
\hline No. & $\begin{array}{c}\text { Inisial Subjek } \\
\text { Penelitian }\end{array}$ & NPM & L/P & $\begin{array}{c}\text { Skor } \\
\text { GEFT }\end{array}$ & $\begin{array}{c}\text { Mengemukakan } \\
\text { Pendapat } \\
\text { Secara Lisan }\end{array}$ & Kategori Gaya Kognitif \\
\hline 1 & HI & 166411043 & $\mathrm{P}$ & 17 & Jelas & Field Independent \\
\hline 2 & NAF & 16641152 & $\mathrm{P}$ & 11 & Jelas & Field Medium \\
\hline 3 & VLD & 166411294 & $\mathrm{P}$ & 2 & Jelas & Field Dependent \\
\hline
\end{tabular}

Pengumpulan data dilakukan dengan triangulasi data, yaitu dengan teknik tes dan teknik wawancara. Setelah subjek penelitian mengerjakan soal tes kemampuan koneksi matematis yang sebelumnya sudah divalidasi terlebih dahulu oleh validator dan melalui ujicoba, kemudian dilanjutkan dengan proses wawancara. Setelah proses wawancara selesai dilakukan, peneliti melakukan analisis terhadap hasil tes kemampuan koneksi matematis subjek penelitian. Berikut akan dipaparkan hasil triangulasi datanya.

\section{Kemampuan Koneksi Matematis Subjek Field Independent}

Berikut akan disajikan triangulasi data terhadap hasil tes kemampuan koneksi matematis dan hasil wawancara subjek dengan gaya kognitif Field Independent.

Tabel 3. Hasil Triangulasi Data Subjek HI

\begin{tabular}{|c|c|c|}
\hline $\begin{array}{c}\text { Indikator } \\
\text { Kemampuan } \\
\text { Berpikir Kritis } \\
\text { Matematis } \\
\end{array}$ & Hasil Tes Tertulis & Hasil Wawancara \\
\hline $\begin{array}{c}\text { Memahami } \\
\text { dan } \\
\text { menggunakan } \\
\text { koneksi di } \\
\text { antara topik- } \\
\text { topik dalam } \\
\text { matematika } \\
\text { (Koneksi antar } \\
\text { konsep } \\
\text { matematika) }\end{array}$ & $\begin{array}{l}\text { Subjek HI } \\
\text { - Subjek HI langsung membagi panjang } \\
\text { kedua kawat menjadi dua bagian sama } \\
\text { panjang, sehingga panjang masing-masing } \\
\text { kawat adalah } 8 \mathrm{~cm} \text {, padahal disoal tidak } \\
\text { dinyatakan bahwa panjang kedua kawat } \\
\text { adalah sama, dan panjang masing-masing } \\
\text { bagian itulah yang ingin dicari dari soal. } \\
\text { - Setelah mendapatkan panjang masing- } \\
\text { masing kawat, subjek HI langsung } \\
\text { menentukan panjang sisi dari masing- } \\
\text { masing bangun yang dibentuk. Untuk } \\
\text { bangun pertama yaitu segitiga sama sisi, } \\
\text { subjek HI menyatakan bahwa panjang } \\
\text { sisinya adalah } 8 / 3 \text {. Karena segitiga sama sisi } \\
\text { punya } 3 \text { sisi, maka panjang } 1 \text { sisinya adalah } \\
22 / 3 \text { cm. Selanjutnya untuk panjang sisi } \\
\text { bangun kedua adalah } 2 \text { cm. Padahal yang } \\
\text { dibutuhkan dari soal bukan mencari } \\
\text { panjang masing-masing sisi-sisinya, } \\
\text { melainkan informasi dari bagian-bagian } \\
\text { persegi dan segitiga itu sendiri. } \\
\text { Subjek HI menyatakan bahwa konsep yang } \\
\text { harus digunakan adalah konsep pembagian, } \\
\text { konsep luas persegi dan segitiga. Subjek HI } \\
\text { sama sekali tidak ada menyebutkan konsep } \\
\text { turunan }\end{array}$ & $\begin{array}{l}\text { Subjek HI } \\
\text { - Subjek HI hanya menyatakan bahwa } \\
\text { konsep yang dibutuhkan adalah } \\
\text { konsep pembagian, sedangkan apa } \\
\text { yang ditulis bukan konsep pembagian } \\
\text { melainkan konsep luas persegi dan } \\
\text { segitiga. } \\
\text { - Konsep pembagian ternyata oleh } \\
\text { subjek HI digunakan untuk } \\
\text { menentukan panjang masing-masing } \\
\text { bagian kawat, sehingga subjek HI } \\
\text { mendapatkan panjang masing-masing } \\
\text { kawat adalah } 8 \text { cm. apa yang } \\
\text { dilakukan oleh subjek HI adalah } \\
\text { salah. } \\
\text { Subjek HI menyatakan hanya dengan } \\
\text { membagi kedua kawat sama } \\
\text { panjanglah baru bisa ditemukan } \\
\text { selesaian dari masalah yang diberikan, } \\
\text { padahal tidak demikian }\end{array}$ \\
\hline $\begin{array}{l}\text { Menerapkan } \\
\text { matematika } \\
\text { dalam bidang } \\
\text { lain (Koneksi } \\
\text { matematika } \\
\text { dengan disiplin } \\
\text { ilmu lain) } \\
\end{array}$ & $\begin{array}{l}\text { Subjek HI } \\
\text { - Subjek HI memberikan selesaian hanya } \\
\text { sampai kepada menemukan nilai t nya saja. } \\
\text { Padahal disoal, diminta setelah menemukan } \\
\text { nilai t, maka tentukan nilai h } \\
\text { maksimumnya. Ada kemungkinan subjek } \\
\text { HI tidak membaca soalnya dengan teliti, hal }\end{array}$ & $\begin{array}{l}\text { Subjek HI } \\
\text { - Subjek HI kurang teliti dalam } \\
\text { membaca soal, tetapi subjek HI sudah } \\
\text { mampu menyelesaikan soal dengan } \\
\text { benar }\end{array}$ \\
\hline
\end{tabular}




\begin{tabular}{|c|c|c|}
\hline & $\begin{array}{l}\text { ini terlihat dari dalam menentukan nilai t, } \\
\text { subjek HI menemukan nilai } t \text { nya dengan } \\
\text { benar }\end{array}$ & \\
\hline $\begin{array}{c}\text { Menerapkan } \\
\text { matematika } \\
\text { dalam } \\
\text { kehidupan } \\
\text { sehari-hari } \\
\text { (Koneksi } \\
\text { matematika } \\
\text { dengan dunia } \\
\text { nyata) }\end{array}$ & $\begin{array}{l}\text { Subjek HI } \\
\text { - Subjek HI menyatakan bahwa konsep yang } \\
\text { dapat digunakan adalah konsep luas } \\
\text { lingkaran. Konsep awal yang dinyatakan } \\
\text { oleh subjek HI sudah benar, tetapi tidak } \\
\text { hanya konsep luas lingkaran yang } \\
\text { dibutuhkan, tetapi konsep turunan juga. } \\
\text { - Dengan rumus luas lingkaran tersebut, } \\
\text { subjek HI menyatakan jari-jari 1, dan } \\
\text { dengan pernyataan berikutnya yaitu } 2 \text { phi = } \\
\text { phi r r maka subjek HI menemukan } \\
\text { panjang jari-jari kedua. Kemudian untuk } \\
\text { mendapatkan pertambahan jari-jari } \\
\text { lingkarannya, subjek HI membagi panjang } \\
\text { jari-jari } 1 \text { dengan jari-jari } 2 \text {. Tentunya apa } \\
\text { yang dilakukan oleh subjek HI adalah salah }\end{array}$ & $\begin{array}{l}\text { Subjek HI } \\
\text { - Subjek HI menyatakan bahwa konsep } \\
\text { yang digunakan adalah luas lingkaran } \\
\text { dengan alasan disoal ada berbicara } \\
\text { tentang lingkaran. } \\
\text { - Subjek HI tidak bisa mengindentifikasi } \\
\text { informasi yang diketahui dengan } \\
\text { benar, sehingga apa yang ditanyakan } \\
\text { juga salah. } \\
\text { - Subjek HI tidak bisa menentukan } \\
\text { bagian mana yang tidak dipahami, } \\
\text { karena subjek HI betul-beutl tidak } \\
\text { memahami soal tersebut. }\end{array}$ \\
\hline \multicolumn{3}{|c|}{$\begin{array}{l}\text { Data Subjek HI yang valid sebagai berikut: } \\
\text { 1. Subjek HI belum memiliki kemampuan memahami dan menggunakan koneksi antar konsep matematika. } \\
\text { 2. Subjek HI memiliki kemampuan menerapkan konsep matematika dengan bidang ilmu lainnya. } \\
\text { 3. Subjek HI belum memiliki kemampuan untuk menerapkan dan menggunakan konsep matematika dengan } \\
\text { dunia nyata. }\end{array}$} \\
\hline
\end{tabular}

\section{Kemampuan Koneksi Matematis Subjek Field Medium}

Berikut akan disajikan triangulasi data terhadap hasil tes kemampuan koneksi matematis dan hasil wawancara subjek dengan gaya kognitif Field Medium.

Tabel 4. Hasil Triangulasi Data Subjek NAF

\begin{tabular}{|c|c|c|}
\hline $\begin{array}{c}\text { Indikator } \\
\text { Kemampuan } \\
\text { Berpikir Kritis } \\
\text { Matematis }\end{array}$ & Hasil Tes Tertulis & Hasil Wawancara \\
\hline $\begin{array}{l}\text { Memahami dan } \\
\text { menggunakan } \\
\text { koneksi di } \\
\text { antara topik- } \\
\text { topik dalam } \\
\text { matematika } \\
\text { (Koneksi antar } \\
\text { konsep } \\
\text { matematika) }\end{array}$ & $\begin{array}{l}\text { Subjek NAF } \\
\text { - Subjek NAF hanya menyatakan } \\
\text { bahwa konsep yang digunakan } \\
\text { adalah konsep turunan dengan } \\
\text { alasan biasanya konsep turunan } \\
\text { dipergunakan untuk menyelesaikan } \\
\text { permasalahan maksimum dan } \\
\text { minimum. Respon yang diberikan } \\
\text { oleh subjek NAF dengan } \\
\text { menyatakan bahwa konsep yang } \\
\text { digunakan adalah turunan, sebagaian } \\
\text { besar sudah mengarahkan kepada } \\
\text { penyelesaian yang diinginkan, tetapi } \\
\text { subjek NAF tidak ada lagi } \\
\text { memberikan respon untuk soal } \\
\text { nomor } 2 \text { ini }\end{array}$ & $\begin{array}{l}\text { Subjek NAF } \\
\text { - } \quad \text { subjek NAF tidak mengetahui konsep lain } \\
\text { yang harus digunakan untuk menyelesaikan } \\
\text { permasalahan yang diberikan selain konsep } \\
\text { turunan. } \\
\text { - } \\
\text { Subjek NAF benar dalam memberikan } \\
\text { alasan pengunaan konsep turunan. } \\
\text { - } \quad \text { Subjek NAF memahami konsep turunan. } \\
\text { - } \quad \text { Subjek NAF tidak dapat menemukan } \\
\text { panjang masing-masing kawat, sehingga } \\
\text { konsep turunan yang sudah dinyatakannya } \\
\text { tidak bisa ia gunakan }\end{array}$ \\
\hline $\begin{array}{l}\text { Menerapkan } \\
\text { matematika } \\
\text { dalam bidang } \\
\text { lain (Koneksi } \\
\text { matematika } \\
\text { dengan disiplin } \\
\text { ilmu lain) }\end{array}$ & $\begin{array}{l}\text { Subjek NAF } \\
\text { - Subjek NAF memberikan jawaban } \\
\text { dengan benar. Dari tulisan subjek } \\
\text { NAF dilembar jawaban terlihat } \\
\text { bahwa subjek NAF memahami } \\
\text { permasalahan yang diberikan. Subjek } \\
\text { NAF memulai menjawab dengan } \\
\text { memulai menggunakan konsep } \\
\text { turunan untuk mendapatkan nilai t }\end{array}$ & $\begin{array}{l}\text { Subjek NAF } \\
\text { - Subjek NAF salah dapat menyatakan } \\
\text { proses menemukan nilai t. } \\
\text { - Subjek NAF juga dapat memberikan alasan } \\
\text { dengan benar, mengapa nilai t harus } \\
\text { ditemukan. } \\
\text { - Subjek NAF juga benar dalam menyatakan } \\
\text { jawabannya }\end{array}$ \\
\hline
\end{tabular}




yang diinginkan, kemudian setelah
didapatkan nilai t, maka nilai t
tersebut disubstitusikan ke dalam
persamaan awal, sehingga dapatlah
tinggi maksimum yang diinginkan

\section{Kemampuan Koneksi Matematis Subjek Field Dependent}

Berikut akan disajikan triangulasi data terhadap hasil tes kemampuan koneksi matematis dan hasil wawancara subjek dengan gaya kognitif Field Dependent

Tabel 5. Hasil Triangulasi Data Subjek VLD

\begin{tabular}{|c|c|c|}
\hline $\begin{array}{c}\text { Indikator } \\
\text { Kemampuan } \\
\text { Berpikir Kritis } \\
\text { Matematis }\end{array}$ & Hasil Tes Tertulis & Hasil Wawancara \\
\hline $\begin{array}{l}\text { Memahami dan } \\
\text { menggunakan } \\
\text { koneksi di antara } \\
\text { topik-topik } \\
\text { dalam } \\
\text { matematika } \\
\text { (Koneksi antar } \\
\text { konsep } \\
\text { matematika) }\end{array}$ & $\begin{array}{l}\text { Subjek VLD } \\
\text { - Subjek VLD menyatakan bahwa } \\
\text { untuk mencari luas dari persegi dan } \\
\text { segitiga sama sisi, maka kita perlu } \\
\text { menggunakan konsep luas bangun } \\
\text { datar. Selanjutnya subjek VLD } \\
\text { menyatakan bahwa panjang sisi dari } \\
\text { persegi dan segitiga sama sisi } \\
\text { tersebut, masing-masing adalah } 8 \\
\text { cm, tanpa menyatakan proses untuk } \\
\text { menemukannya. Subjek VLD juga } \\
\text { menyatakan bahwa rumus luas } \\
\text { segitiga sama sisi adalah s } \times \mathrm{s} \times \mathrm{s} \text {, } \\
\text { tentu hal ini kurang tepat }\end{array}$ & $\begin{array}{l}\text { Subjek VLD } \\
\text { - Subjek VLD belum memahami } \\
\text { soal dengan baik. Subjek VLD } \\
\text { juga tidak mengetahui konsep } \\
\text { lain selain konsep luas bangun } \\
\text { datar untuk menyelesaikan } \\
\text { permasalahan yang diberikan. } \\
\text { Selanjutnya subjek VLD juga } \\
\text { salah dalam menyatakan konsep } \\
\text { luas yang diberikan. }\end{array}$ \\
\hline $\begin{array}{c}\text { Menerapkan } \\
\text { matematika } \\
\text { dalam bidang } \\
\text { lain (Koneksi } \\
\text { matematika } \\
\text { dengan disiplin } \\
\text { ilmu lain) }\end{array}$ & $\begin{array}{l}\text { Subjek VLD } \\
\text { - } \text { subjek VLD memberikan jawaban } \\
\text { dengan benar. Dari tulisan subjek } \\
\text { NAF dilembar jawaban terlihat } \\
\text { bahwa subjek VLD memahami } \\
\text { permasalahan yang diberikan. Subjek } \\
\text { VLD memulai menjawab dengan } \\
\text { memulai menggunakan konsep } \\
\text { turunan untuk mendapatkan nilai t } \\
\text { yang diinginkan, kemudian setelah } \\
\text { didapatkan nilai t, maka nilai t } \\
\text { tersebut disubstitusikan ke dalam } \\
\text { persamaan awal, sehingga dapatlah } \\
\text { tinggi maksimum yang diinginkan }\end{array}$ & $\begin{array}{l}\text { Subjek VLD } \\
\text { - Subjek NAF salah dapat } \\
\text { menyatakan proses menemukan } \\
\text { nilai t. } \\
\text { - Subjek NAF juga dapat } \\
\text { memberikan alasan dengan } \\
\text { benar, mengapa nilai t harus } \\
\text { ditemukan. } \\
\text { - Subjek VLD juga benar dalam } \\
\text { menyatakan jawabannya. }\end{array}$ \\
\hline
\end{tabular}




\begin{tabular}{|c|c|c|}
\hline $\begin{array}{c}\text { Menerapkan } \\
\text { matematika } \\
\text { dalam kehidupan } \\
\text { sehari-hari } \\
\text { (Koneksi } \\
\text { matematika } \\
\text { dengan dunia } \\
\text { nyata) }\end{array}$ & $\begin{array}{l}\text { Subjek NAF } \\
\text { - subjek VLD tidak memahami apa } \\
\text { yang diinginkan dari soal, yang } \\
\text { dinginkan dari soal adalah panjang } \\
\text { jari-jari noda minyak dengan laju } \\
\text { pertambahan yang sudah ditentukan, } \\
\text { tetapi apa yang dilakukan oleh subjek } \\
\text { VLD bukan untuk menemukan } \\
\text { panjang jari-jarinya, hal ini ditandai } \\
\text { dengan jawaban akhir yang diberikan } \\
\text { oleh subjek VLD, yaitu } 8 \text { phi cm/ } \\
\text { detik. (2) subjek VLD salah dalam } \\
\text { memahami bahwa yang diberikan } \\
\text { adalah laju pertambahan, tetapi yang } \\
\text { dipahami oleh subjek VLD adalah } \\
\text { laju pertambahan tersebut sebagai } \\
\text { jari-jari. (3) subjek VLD hanya } \\
\text { menyatakan konsep yang digunakan } \\
\text { adalah konsep lingkaran, padahal } \\
\text { bukan hanya konsep lingkaran tetapi } \\
\text { juga menggunakan konsep turunan }\end{array}$ & $\begin{array}{l}\text { Subjek NAF } \\
\text { - Subjek VLD belum memahami } \\
\text { soal dengan baik, hal ini terlihat } \\
\text { dari subjek VLD salah dalam } \\
\text { memahami nilai laju } \\
\text { pertambahan yang diberikan. } \\
\text { Subjek VLD menganggap nilai } \\
\text { laju pertambahan yang diberikan } \\
\text { adalah jari-jari yang harus } \\
\text { disubstitusikan dipersamaan } \\
\text { lingkaran yang dinyatakannya. } \\
\text { Subjek VLD juga tidak dapat } \\
\text { menyatakan konsep apal agi yang } \\
\text { dapat digunakan untuk } \\
\text { menyelesaikan permasalahan } \\
\text { yang diberikan. }\end{array}$ \\
\hline \multicolumn{3}{|c|}{$\begin{array}{l}\text { Data Subjek VLD yang valid sebagai berikut: } \\
\text { 1. Subjek VLD belum memiliki kemampuan memahami dan menggunakan koneksi antar konsep } \\
\text { matematika. } \\
\text { 2. Subjek VLD memiliki kemampuan menerapkan konsep matematika dengan bidang ilmu lainnya. } \\
\text { 3. Subjek VLD belum memiliki kemampuan untuk menerapkan dan menggunakan konsep } \\
\text { matematika dengan dunia nyata. }\end{array}$} \\
\hline
\end{tabular}

Berdasarkan paparan di atas (Tabel 3, 4, dan 6), terlihat bahwa subjek penelitian dengan kognitif Field Independent, Field Medium dan Field Dependent sama-sama menjawab dengan benar soal tes yang mewakili indikator kemampuan menerapkan koneksi matematika dengan bidang disiplin ilmu lainnya. Sedangkan untuk kedua indikator kemampuan koneksi lainnya, masing-masing subjek dari masing-masing kategori gaya kognitif, belum mampu menjawab dengan benar soal tes yang mewakili kedua indikator tersebut. Namun demikian, terdapat perbedaan yang diperilhatkan oleh masing-masing subjek dari masing-masing kategori gaya kognitif dalam menyelesaikan kedua soal tes tersebut.

Untuk soal tes yang mewakili indikator kemampuan mengkoneksikan konsep matematika dengan konsep matematika lainnya, subjek dengan gaya kognitif Field Independent dan Field Dependent sama-sama mencoba menjawab dengan mencoba mencari panjang masing-masing kawat dan hanya menyatakan sebagian konsep yang benar, yaitu konsep luas persegi dan segitiga. Walaupun menyatakan konsep luas persegi dan segitiga, subjek Field Dependent salah dalam menuliskan rumus luas segitiga, sedangkan subjek Field Independent benar dalam menyatakan rumus luas tersebut. Ini terlihat bahwa subjek Field Independent lebih memahami dan memiliki penguasaan matematika yang lebih baik dari subjek Field Dependent. Sebaliknya subjek Field Medium hanya menyatakan konsep yang digunakan adalah konsep turunan, tetapi sama sekali tidak menuliskan bagaimana aplikasi konsep turunan tersebut dalam menyelesaikan masalah. Jika dibandingkan dengan subjek Field Dependent dan Subjek Field Independent, subjek Field Medium sudah menyatakan konsep utama yang dibutuhkan.

Dalam hal ini terlihat sekali jika subjek Field Medium terlalu berhati-hati, memiliki penguasaan yang baik, tetapi kurang dalam hal menganalisis. Sebaliknya subjek Field Independent mencoba menjawab dengan apa yang dipikirkannya, menganalisis dan memiliki penguasaan konsep yang lebih baik. Sedangkan subjek Field Dependent mencoba menjawab, tetapi tidak memiliki kemampuan analisis dan penguasaan konsep yang baik.

Untuk soal tes yang mewakili indikator kemampuan mengkoneksikan konsep matematika dalam permasalahan sehari-hari, subjek dari ketiga kategori gaya kognitif tidak dapat memberikan selesaian dengan benar. Namun demikian, subjek dengan gaya kognitif Field Medium tidak 
memberikan respon sama sekali. Sedangkan subjek dengan gaya kognitif Field Independent dan Field Dependent sama-sama menggunakan konsep luas lingkaran. Subjek Field Independent memahami bahwa yang ingin dicari adalah panjang jari-jari, sedangkan subjek Field Dependent tidak memahami bahwa yang ingin dicari adalah panjang jari-jari. Hal ini terlihat bahwa subjek Field Dependent kurang dalam melakukan analisa.

\section{KESIMPULAN DAN SARAN}

Berdasarkan hasil penelitian dan pembahasan di atas, maka dapat disimpulkan bahwa kemampuan koneksi matematis mahasiswa jika ditinjau dari gaya kognitif (Field Independent, Field Medium, dan Field Dependent) masih kurang. Hal ini dapat dilihat dari tiga soal yang masing-masing mewakili tiga indikator kemampuan koneksi yang peneliti teliti, hanya satu soal yang dijawab dengan benar oleh masing-masing subjek dengan masing-masing kategori gaya kognitif. Walaupun demikian, masing-masing subjek dengan masing-masing kategori gaya kognitif memiliki cara yang berbeda dalam menyelesaikan permasalahan tersebut yang sesuai dengan cara mereka berpikir.

Bagi pengajar yang ingin meningkatkan kemampuan koneksi matematis mahasiswa tersebut, maka ada beberapa cara yang dapat dilakukan yang sesuai dengan hasil yang telah dipaparkan dalam penelitian ini, diantaranya yaitu: (1) Jika ingin meningkatkan kemampuan koneksi matematis mahasiswa tersebut, maka langkah perbaikan yang harus dilakukan adalah membiasakan mahasiswa dalam menyelesaikan soal-soal yang dikaitkan dengan indikator kemampuan koneksi, terutama soal-soal kalkulus 1 yang mengkoneksikan konsep kalkulus 1 dengan konsep matematika lainnya dan mengkoneksikan konsep kalkulus 1 dengan permasalahan sehari-hari; (2) walaupun dibidang pendidikan matematika, pengajaran kalkulus 1, dianggap perlu untuk mengajarkan aplikasi dari penerapan kalkulus 1 tersebut; (3) penggunaan model, pendekatan, strategi, teknik, atau metode harus menjadi pertimbangan bagi pengajar yang mengajar mahasiswa tersebut, karena sebagian besar adalag bergaya kognitif Field Dependent, sehingga pengajar dirasa perlu untuk mengkaji bagaimanakah ciri-ciri dari individu Field Dependent tersebut, sehingga pemilihan dan penggunaan model menjadi tepat dan bermanfaat.

\section{DAFTAR PUSTAKA}

Emzir. (2012). Metodologi Penelitian Kualitatif (Analisis Data). Jakarta: Rajawali Pers.

Ulya, Himmatul. (2015). Hubungan Gaya Kognitif Dengan Kemampuan Pemecahan Masalah Matematika Siswa. Jurnal Konseling GUSJIGANG, Vol. 1 No. 2 Tabun 2015, ISSN. 24601187.

Martono, Koko. (1999). Kalkulus. Jakarta: Erlangga.

Moleong, Lexy J. (2014). Metode Penelitian Kualitatif Edisi Revisi. Bandung: Rosdakarya.

National Council of Teachers of Mathematics (NCTM). (2000). Principles and standard for School Mathematics. Reston: NCTM.

Suryanti, Nunuk. (2014). Pengaruh Gaya Kognitif Terhadap Hasil Belajar Akuntansi Keuangan Menengah 1. Jurnal Ilmiah Akuntansi dan Humanika Jinah, Vol. 4 No. 1, Singaraja, Desember 2014. ISSN. 2089-3310.

Sternberg, R. J. dan Elena L. G. (1997). Are Cognitive Styles Still in Style?. Amaerican Psychologist Association. Volume 52, No. 7 PP. 700-712.

Sumarmo, Utari. (2013). Kumpulan Makalah Berpikir dan Disposisi Matematik Serta Pembelajarannya. Bandung: UPI

Witkin, H. A., et al. (1977). Field Dependent and Field Independent Cognitive Styles and Their Educational Implications. Review of Educational Research. Volume 47, No. 1. PP. 1-64.

Anita E, Woolfolk. (1993). Educational Psychology. London: Allyn and Bacon. 